\title{
Formas de utilização do milho em suplementos para novilhos na fase de terminação em pastagem no período das águas: desempenho e parâmetros nutricionais $^{1}$
}

\author{
Marlos Oliveira Porto ${ }^{2}$, Mário Fonseca Paulino ${ }^{3}$, Sebastião de Campos Valadares Filho ${ }^{3}$, \\ Maykel Franklin Lima Sales ${ }^{2}$, Edenio Detmann ${ }^{3}$, Jucilene Cavali ${ }^{2}$
}

\footnotetext{
1 Pesquisa parcialmente financiada pela FAPEMIG e pelo CNPq

2 Doutorando DZO/UFV. Bolsista do CNPq.

${ }^{3}$ DZO/UFV. Bolsista do CNPq.
}

RESUMO - Avaliou-se a influência da forma de utilização do milho em suplementos no desempenho de novilhos na fase de terminação, durante o período das águas, em pastagem de capim-braquiária. Utilizaram-se 16 bovinos mestiços com peso inicial de $384 \mathrm{~kg}$ e 18 meses de idade, distribuídos em delineamento inteiramente casualizado, com quatro tratamentos - mistura mineral (MM) (controle); milho triturado (MT); milho desintegrado com sabugo (MDS); e milho desintegrado com palha e sabugo (MDPS) - e quatro repetições. Os animais foram mantidos em pastagem de 6 ha de Brachiaria decumbens Stapf, dividida em quatro piquetes de 1,5 ha, com disponibilidade de matéria seca total (MST) de 4,77 t/ha e MSpd (matéria seca potencialmente digestível) de 3,14 t/ha. Para avaliação dos parâmetros nutricionais, utilizaram-se quatro animais mestiços fistulados no esôfago, no rúmen e no abomaso, com peso médio inicial de $390 \mathrm{~kg}$, distribuídos em quadrado latino $4 \times 4$, composto de quatro tratamentos e quatro períodos experimentais. Os animais do grupo controle receberam mistura mineral diariamente (60 g/dia), enquanto os demais receberam os suplementos (1,0 kg/dia). Os suplementos múltiplos não influenciaram o desempenho dos animais, mas as concentrações séricas de uréia foram maiores nos animais sob suplementação. O consumo de PB, assim como a digestibilidade total de $\mathrm{PB}$, aumentou com o uso dos suplementos múltiplos. Os animais do grupo controle (mistura mineral) apresentaram maior consumo de matéria seca e matéria orgânica de pasto. O uso de suplemento múltiplo (1 kg/dia) no período das águas promoveu aumento numérico de até $165 \mathrm{~g} /$ animal em relação à suplementação com mistura mineral. O milho desintegrado com palha e sabugo e o milho desintegrado com sabugo equivalem ao grão de milho triturado.

Palavras-chave: gado de corte, ganho de peso, pasto, suplementação

\section{Corn, in different forms, in multiple supplements for finishing crossbred steers on pasture during rainy season: performance and nutrition parameters}

\footnotetext{
ABSTRACT - The effect of corn feeding forms in multiple supplements on performance of finishing steers grazing signal grass (Brachiaria decumbens Stapf) during rainy season was evaluated. Sixteen crossbred steers with initial weight of $384 \mathrm{~kg}$ and 18 mo old were distributed to four supplements - mineral mix (MM) (control) and three multiple supplements with different feeding forms of corn: ground corn (GC); ground ear-corn (GEC) and ground whole-plant corn (GWPC) - in a completely randomized experimental design with four replicates. The animals were kept in pasture, 6 ha of signal grass, divided into four paddocks of 1.5 ha, with total dry matter and potentially digestible dry matter availabilities of $4.77 \mathrm{t} / \mathrm{ha}$ and $3.14 \mathrm{t} / \mathrm{ha}$, respectively. Four esophagus, rumen and abomasum fistulated crossbred animals with initial weight of $390 \mathrm{~kg}$, were used to evaluate the nutritional parameters. Animals were distributed to a $4 \times 4$ Latin square, composed of four supplements and four experimental periods. The animals in the control group were fed daily with $60 \mathrm{~g} / \mathrm{day}$ of $\mathrm{MM}$, while the others were fed with $1.0 \mathrm{~kg} /$ day of the multiple supplements different. Multiple supplements did not influence the performance of animals, but serum urea concentrations were higher in animals fed with the different multiple supplements. Crude protein and intake and digestibility increased with the use multiple supplements. Animals of the control showed higher dry matter and organic matter intake from the pasture. The different multiple supplements $(1 \mathrm{~kg} /$ day) promoted numerical increase of up to $165 \mathrm{~g} / \mathrm{animal} / \mathrm{day}$ in relation to control during rainy season. Ground whole-plant corn and ground ear-corn are equivalent to ground corn for steers in the finishing phase in pasture in the rainy season.
}

Key Words: beef cattle, pasture, supplementation, weight gain 


\section{Introdução}

Nos últimos anos, o desafio de explorar o máximo potencial genético dos animais e disponibilizar os nutrientes potencialmente digestíveis do pasto durante o período das águas via administração de suplementos múltiplos tem sido apresentado aos centros de pesquisa pecuária e aos produtores. A suplementação alimentar no período chuvoso tem como finalidade reduzir deficiências dietéticas das forragens e permitir ao animal aumentar o consumo de nutrientes digestíveis. Assim, a produtividade e a eficiência alimentar, fatores necessários na pecuária de ciclo curto, são melhoradas e possibilitam obter peso e composição de carcaça para abate em menor idade, de modo que o animal proveniente de uma estação de nascimento, nas condições do Brasil Central, de setembro a novembro pode não passar por uma segunda estação seca.

Segundo Cappelle et al. (2001), a utilização dos alimentos depende dos ingredientes presentes na dieta, da taxa de digestão ruminal de proteínas e carboidratos, da taxa de passagem, das exigências de mantença e crescimento de bactérias ruminais, da taxa de produção de amônia ruminal, da digestibilidade intestinal e das condições ambientais.

Entre os concentrados energéticos utilizados na suplementação animal, destaca-se o milho, amplamente utilizado em todo o Brasil. Na substituição desse alimento podem ser empregados alimentos alternativos, como sorgo, polpa cítrica, farelo de trigo, aveia, farelo de arroz, subprodutos de mandioca, casca de café, casca de soja e outros, cuja disponibilidade varia entre regiões. O milho desintegrado com palha e sabugo é muito usado entre pequenos produtores, principalmente durante a seca, em razão de sua praticidade e do preço de mercado, que geralmente é menor que o do grão de milho, e pode ser uma alternativa para utilização em suplementos múltiplos.

Objetivou-se avaliar o efeito da forma de utilização do milho em suplementos múltiplos sobre o desempenho e os parâmetros nutricionais de bovinos em terminação em pastagem de Brachiaria decumbens durante o período das águas.

\section{Material e Métodos}

O experimento foi conduzido nas dependências da Central de Experimentação Pesquisa e Extensão do Triângulo Mineiro, pertencente à Universidade Federal de Viçosa, localizada no município de Capinópolis, Minas Gerais, durante o período das águas, entre os meses de dezembro de 2003 a fevereiro de 2004, onde o clima é do tipo AW, segundo classificação de Köpper, quente e úmido, com
(A)

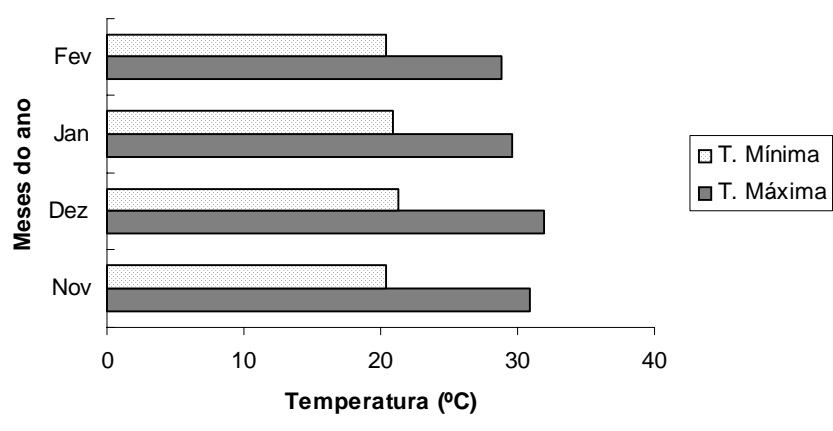

(B)

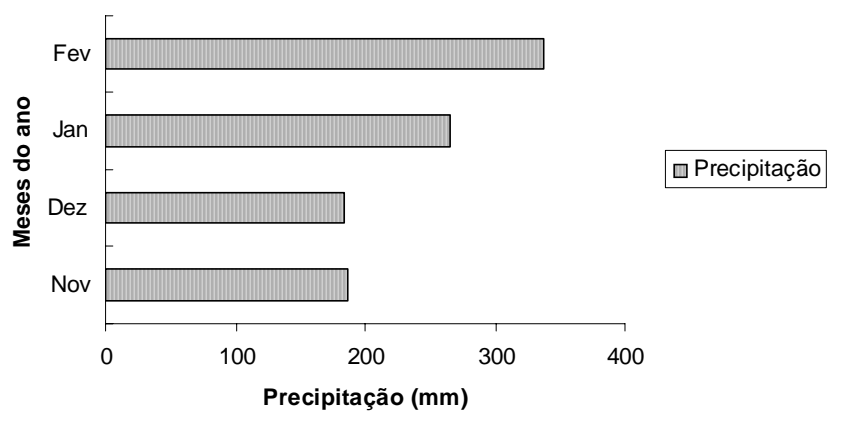

Figura 1 - Temperaturas médias máximas e mínimas $\left({ }^{\circ} \mathrm{C}\right)$ e precipitação $(\mathrm{mm})$ nos meses de novembro de 2003 a fevereiro de 2004.

temperatura do mês mais frio acima de $18^{\circ} \mathrm{C}$, estação chuvosa no verão e seca no inverno, apresentando precipitações médias anuais entre 1.400 e 1.600 mm.

Utilizaram-se 16 novilhos mestiços (Holandês $\times$ Zebu), não-castrados, com 18 meses de idade e $380 \mathrm{~kg}$ de peso inicial, submetidos ao consumo diário de suplemento (1,0 kg/animal) durante os três meses que antecederam o experimento.

Os animais foram distribuídos aleatoriamente em quatro piquetes de Brachiaria decumbens Stapf (de 1,5 ha cada um), providos de bebedouros e comedouros cobertos de modo que em cada piquete foi fornecido um tipo de suplemento. Avaliaram-se quatro suplementos: MM - mistura mineral (controle); MT - milho triturado + farelo de algodão + uréia + sulfato de amônio (9:1) + mistura mineral; MDS milho desintegrado com sabugo + farelo de algodão + uréia/sulfato de amônio + mistura mineral; MDPS - milho desintegrado com palha e sabugo + farelo de algodão + uréia/sulfato de amônio + mistura mineral (Tabela 1). Os suplementos foram fornecidos diariamente, em comedouro coletivo, na quantidade de $60 \mathrm{~g} / \mathrm{animal}$ (no caso da mistura mineral) e $1,0 \mathrm{~kg} /$ animal (demais suplementos), às $10 \mathrm{~h}$, visando fornecer 30\% do teor de proteína bruta necessário 
para animais em terminação com $400 \mathrm{~kg}$ de peso vivo nesta fase, esses animais necessitam de 0,913 kg de PB, segundo o NRC (1996).

Os animais foram pesados no início do experimento e a cada 28 dias, sem jejum, sempre pela manhã.

O experimento foi composto de três períodos, cada um com 28 dias, totalizando 84 dias. A cada sete dias, os animais foram rotacionados entre os piquetes, visando à eliminação de possíveis efeitos de piquete sobre o desempenho dos animais.

O ganho de peso total (GPT) foi determinado pela diferença entre o peso final e o peso inicial e o ganho médio diário (GMD) foi obtido dividindo-se o ganho de peso total pelo número de dias de duração do experimento (84 dias). Ao final do período de avaliação, os animais foram abatidos após jejum de 14 horas. O rendimento de carcaça (RC) foi calculado como a razão entre o peso da carcaça quente e o peso vivo em jejum.

No quinto dia de cada período experimental, foi realizada a amostragem do pasto consumido pelos animais para a avaliação qualitativa. Utilizaram-se animais fistulados no esôfago para obtenção de amostras de extrusa esofágica, que foram posteriormente compostas em amostra única por período.

As análises dos teores de matéria seca, matéria orgânica, extrato etéreo, fibra em detergente neutro (FDN), fibra em detergente ácido (FDA) e dos compostos nitrogenados totais foram realizadas de acordo com técnicas descritas por Silva \& Queiroz (2002). A fibra em detegente neutro indigestível (FDNi) foi determinada na amostra obtida com o quadrado de $0,25 \mathrm{~m}^{2}$ para estimativa da disponibilidade de matéria seca potencialmente digestível do pasto, obtida pela digestibilidade in situ por 144 horas. A fibra em detegente neutro potencialmente digestível (FDNpd) foi determinada utilizando-se a equação: $F D N p d=F D N-F D N i$.

Os teores de compostos nitrogenados não-protéicos (CNNP), nitrogênio insolúvel em detergente neutro (NIDN) e nitrogênio insolúvel em detergente ácido (NIDA) foram estimados conforme descrito por Licitra et al. (1996), enquanto os carboidratos totais (CT) foram calculados como: $\mathrm{CT}=100-(\% \mathrm{~PB}+\% \mathrm{EE}+\%$ Cinzas $)$.

No quinto dia de cada período experimental, realizou-se a coleta do pasto por meio do corte, rente ao solo, de cinco áreas delimitadas por um quadrado metálico de $0,25 \mathrm{~m}^{2}$, selecionadas aleatoriamente em cada piquete experimental (McMeniman, 1997). As amostras foram pesadas e mantidas em estufa com ventilação forçada a $65^{\circ} \mathrm{C}$, por 72 horas, para determinação da disponibilidade total de matéria seca e matéria seca potencialmente digestível (MSpd) da pastagem, conforme descrito por Paulino et al. (2006), pela seguinte equação: $\mathrm{MSpd}=0,98(100-\mathrm{FDN})+(\mathrm{FDN}-\mathrm{FDNi})$

Os carboidratos não-fibrosos (CNF) foram quantificados segundo recomendações de Hall (2000), em virtude da inclusão de uréia na formulação dos suplementos, utilizando-se a seguinte equação: $\mathrm{CNF}=100-[(\% \mathrm{~PB}-\% \mathrm{~PB}$ da uréia +\% de uréia) +\%FDNcp + \%EE + \%cinzas], em que FDNcp = fibra em detergente neutro isenta de cinzas e proteína.

Considerando a composição química dos alimentos, foram obtidos os teores de nutrientes digestíveis totais estimados $\left(\mathrm{NDT}_{\mathrm{EST}}\right)$, segundo equações sugeridas pelo NRC(2001).

Realizou-se, no 14을 dia do segundo período experimental, a coleta de sangue por punção da veia jugular utilizando-se agulha e tubos a vácuo com gel acelerador da coagulação. As amostras foram mantidas em descanso por uma noite em geladeira para obtenção do soro, que foi congelado a $-20^{\circ} \mathrm{C}$

Tabela 1 - Composição percentual, com base na matéria natural, e teores de proteína bruta e proteína degradável no rúmen determinados nos suplementos avaliados

\begin{tabular}{|c|c|c|c|c|}
\hline \multirow[t]{2}{*}{ Item } & \multicolumn{4}{|c|}{ Tipo de suplemento } \\
\hline & Mistura mineral & Milho triturado & $\begin{array}{l}\text { Milho desintegrado } \\
\text { com sabugo }\end{array}$ & $\begin{array}{l}\text { Milho desintegrado } \\
\text { com palha e sabugo }\end{array}$ \\
\hline
\end{tabular}

Ingrediente (\%)

Mistura mineral

Uréia/SA (9:1)

Farelo de algodão 38\% PB

Grão de milho triturado

Milho desintegrado com sabugo

Milho desintegrado com palha e sabugo ${ }^{2}$

Composição

$\begin{array}{cc}100,0 & 5,0 \\ - & 5,0 \\ - & 15,0 \\ - & 75,0 \\ - & - \\ - & -\end{array}$

$$
\begin{gathered}
5,0 \\
5,0 \\
15,0 \\
- \\
75,0
\end{gathered}
$$$$
-
$$

$\begin{array}{cc}5,0 & 5,0 \\ 5,0 & 5,0 \\ 15,0 & 15,0 \\ - & - \\ 75,0 & - \\ - & 75,0\end{array}$

${ }^{1}$ Estimada utilizando-se valores da Tabela de Composição de Alimentos para Bovinos (Valadares Filho et al., 2002).

$\begin{array}{lll}23,14 & 22,73 & 22,63 \\ 78,66 & 81,05 & 81,70\end{array}$


para posteriores avaliações das concentrações séricas de uréia utilizando-se kits comerciais.

Os dados obtidos no experimento foram analisados em delineamento inteiramente casualizado, adotando-se o peso vivo inicial como co-variável. As comparações entre médias de tratamentos foram realizadas pelo teste de média, adotando-se o teste de diferença mínima significativa (DMS) de Fisher $(\alpha=0,10)$.

Para a avaliação dos parâmetros nutricionais, foram utilizados quatro novilhos $1 \frac{1}{2}$ Holandês $\times$ Zebu, não-castrados, com peso médio inicial de $390 \mathrm{~kg}$, fistulados no esôfago, rúmen e abomaso, segundo recomendações de Leão et al. (1978), mantidos em área experimental composta de quatro piquetes de Brachiaria decumbens, Stapf (0,4 ha cada um), providos de bebedouros e comedouros em área coberta. Os tratamentos, os animais e os piquetes foram sorteados em cada período experimental.

O experimento foi conduzido em quadrado latino $4 \times 4$, com quatro tratamentos e quatro períodos experimentais, cada um com 14 dias de duração, de modo que os setes primeiros dias foram destinados à adaptação dos animais.

No quinto dia do período experimental, foi coletada amostra do pasto nos piquetes utilizando-se o mesmo método adotado no experimento para avaliação do desempenho produtivo. A amostragem do pasto consumido foi feita no quinto dia do período experimental, via coleta de extrusa, utilizando-se animais fistulados no esôfago. No dia anterior à coleta, os animais fistulados foram submetidos a jejum de 13 horas para evitar que houvesse regurgitação durante a coleta. Os procedimentos utilizados foram a retirada da cânula, o acoplamento da bolsa de fundo telado e a condução dos animais aos piquetes para pastejo por aproximadamente 40 minutos.

Entre o $3^{\text {o }}$ e o $13^{\circ}$ dia experimental, realizou-se o fornecimento de óxido crômico aos animais, na quantidade de $15 \mathrm{~g}$ de por dia. O óxido crômico foi acondicionado em cartuchos de papel e introduzido diretamente no rúmen dos animais fistulados, sempre às $11 \mathrm{~h}$.

Realizaram-se seis coletas de fezes e de digesta abomasal de cada animal por período experimental: a primeira no oitavo dia do período, às 8 h e a cada 26 horas nos dias subseqüentes, até o $13^{0}$ dia, às $18 \mathrm{~h}$. As amostras de fezes e digesta abomasal foram identificadas e secas em estufa de ventilação forçada a $65^{\circ} \mathrm{C}$ por aproximadamente 72 horas. Após esse período, as amostras foram pesadas, trituradas em moinho com peneira com porosidade de $1 \mathrm{~mm}$ e armazenadas como amostras compostas por animal no período em potes de vidro devidamente identificados.

As concentrações de FDNi e a FDAi foram determinadas nas amostras de suplementos, de fezes, do conteúdo abomasal e da extrusa esofágica, acondicionadas em sacos do tipo ANKOM, por meio da degradabilidade in situ por 144 horas.

A fibra em detergente ácido indigestível (FDAi) foi utilizada como indicador para estimar o fluxo de matéria seca abomasal e determinada segundo técnica descrita por Cochran et al. (1986), estabelecendo-se a relação entre a ingestão diária do indicador e sua concentração no abomaso, segundo a equação:

$$
F M A=\frac{E F x C I F}{C I A B} \times 100,
$$

em que: FMA = fluxo de MS abomasal (kg/dia); EF = excreção fecal (kg/dia); CIF = concentração do indicador nas fezes $(\mathrm{kg} / \mathrm{kg}) ;$ CIAB = concentração do indicador no abomaso $(\mathrm{kg} / \mathrm{kg})$.

A estimação do consumo voluntário foi realizada empregando-se como indicador interno a FDAi, conforme a equação descrita por Detmann et al. (2001a):

CMS $(\mathrm{kg} / \mathrm{dia})=\{[($ EFxCIF $)-I S] / C I F O\}+$ CMSS, em que: IS = indicador presente no suplemento ( $\mathrm{kg} / \mathrm{dia})$; CIFO = concentração do indicador na forragem $(\mathrm{kg} / \mathrm{kg})$; e CMSS = consumo de MS do suplemento (kg/dia).

A excreção de matéria seca fecal foi estimada utilizando-se o óxido crômico e calculada como:

Matéria sec a fecal (g / dia $)=\frac{\text { Quantidade fornecida do indicador (g) }}{\text { Concentração do indicador nas fezes (\%) }}$ x100

O coeficiente de substituição (CS, g de MS de suplemento/g de MS de forragem) foi calculado usando a seguinte equação:

CS $(\mathrm{Ti})=\{[$ CMSfor T1 (g/kg PV) - CMSfor Ti $(g / k g ~ P V)] /$ [CMSsupl Ti (g/kg PV)]\}

em que: $\mathrm{CS}(\mathrm{Ti})$ = coeficiente de substituição no tratamento i; CMSfor T1 (g/kg PV) = consumo diário de matéria seca de forragem pelo animal do tratamento-referência (g/kg PV); CMSfor Ti (g/kg PV) = consumo diário de matéria seca de forragem pelo animal no tratamento $\mathrm{Ti}$, em (g/kg PV); CMSsupl Ti (g/kg PV) = consumo de matéria seca de suplemento pelo animal no tratamento Ti.

Os teores de proteína degradável no rúmen (PDR) foram estimados segundo recomendações do NRC (2001). Foram utilizados os seguintes valores das frações (a) e (b) e a taxa de degradação da fração b (c) 21,93; 74,21; 4,03 para o milho, 30,20; 65,70; 5,00 para o milho desintegrado com palha e sabugo e 30,44; 57,39; 7,46 para o farelo de algodão (Valadares Filho et al., 2002). O valor de Kp utilizado foi de 5,00\%/h.

As análises para determinação dos teores de matéria seca, matéria orgânica, proteína bruta, extrato etéreo, fibra em detergente neutro e fibra em detergente ácido foram 
realizadas de acordo com as técnicas descritas por Silva \& Queiroz (2002). Os teores de compostos nitrogenados não-protéicos (CNNP), nitrogênio insolúvel em detergente neutro (NIDN) e nitrogênio insolúvel em detergente ácido (NIDA) foram determinados conforme descrição de Licitra et al. (1996).

O experimento foi analisado em delineamento quadrado latino e as comparações entre médias de tratamentos foram realizadas pelo teste de média, adotando-se o teste DMS de Fisher $(\alpha=10 \%)$. Os procedimentos estatísticos foram realizados por meio do programa Statistical Analysis System - SAS.

\section{Resultados e Discussão}

Os valores médios de disponibilidade de matéria seca total (MST) e matéria seca potencialmente disponível (MSpd) do pasto foram 4,77 e 3,14 t/ha, respectivamente. Verificou-se aumento das disponibilidades desses componentes no decorrer do experimento, provavelmente em virtude das condições climáticas favoráveis (Figura 2). As disponibilidades de MST e MSpd não limitaram a seletividade dos animais, uma vez que a quantidade considerada por Euclides et al. (1992) como satisfatória para não suprimir a seletividade animal é de 4,26 t de MS/ha, ou seja, neste estudo, apenas no primeiro período essas condições não foram satisfatórias. A taxa de lotação foi de 2,53 UA/ha, o que evidencia uma taxa de lotação moderada para essa época do ano. Desta forma, as disponibilidades médias de MS e MSpd foram 4,98 e 3,28 kg/100 kg de peso vivo, respectivamente.

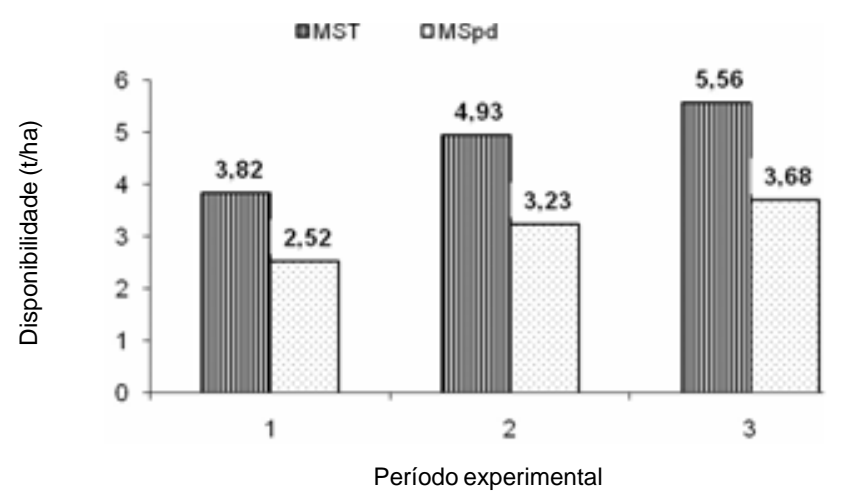

Figura 2 - Disponibilidade de matéria seca total (MST) e de matéria seca potencialmente digestível (MSpd) do pasto nos períodos experimentais.
O teor de proteína bruta do pasto (Tabela 2), de 8,26, foi superior ao de $7 \%$ obtido na forragem, recomendado por Minson (1990) para uma fermentação ruminal que garanta a manutenção do animal. Contudo, foi inferior aos valores de 13-14\% recomendados por Satter \& Slyter (1974), que podem aumentar a taxa de degradação da fibra.

Os valores de FDN e FDNcp obtidos nas amostras de extrusa foram de 65,63 e 59,68\% e são característicos de gramíneas tropicais, uma vez que $25,69 \%$ da FDN estava na forma de FDNi.

O consumo médio de suplemento foi de $0,23 \%$ do PV médio dos animais (Tabela 3), o que evidencia baixo consumo (1 kg/animal). Apesar de relativamente baixo, o consumo de suplemento pelos animais, com fornecimento na quantidade de $1 \mathrm{~kg} / \mathrm{animal}$, no período chuvoso deve ser utilizado com cautela. Quantidades menores de suplementos múltiplos dessa natureza precisam ser testadas quando se aplica essa prática durante o período das águas, pois poderiam proporcionar resposta semelhante à encontrada neste trabalho. Nesse enfoque, é necessária a análise da relação custo/benefício do uso da suplementação no sistema de produção.

As concentrações séricas de uréia (média de 21,07 mg/dL) nos animais sob suplementação foram superiores $(\mathrm{P}<0,10)$ às obtidas com o suplemento controle $(11,50 \mathrm{mg} / \mathrm{dL})$, provavelmente em virtude do consumo do suplemento energéticoprotéico, que levou a maior ingestão de proteína bruta na dieta como um todo. Segundo Valadares et al. (1997a), os níveis plasmáticos de uréia variando de 13,52 e 15,15 mg/dL correspondem à máxima eficiência microbiana e provavelmente representariam o limite no qual estaria ocorrendo perda de proteína nos novilhos zebuínos alimentados com ração com $62,5 \%$ de NDT.

Não foi observada diferença $(\mathrm{P}>0,10)$ para as demais variáveis analisadas. Entretanto, os animais que receberam misturas múltiplas apresentaram aumento numérico de $134 \mathrm{~g}$ no ganho médio diário e chegaram ao final do experimento com peso vivo final numericamente superior $(472,7 \mathrm{~kg}$ vs 461,8 kg do grupo alimentado apenas com mistura mineral). Os novilhos que receberam os suplementos milho desintegrado com sabugo e milho desintegrado com palha e sabugo apresentaram ganhos diários adicionais de 165 e 163 g/animal em relação aos alimentados com mistura mineral. Desta forma, os animais sob suplementação poderiam ter antecipado a idade ao abate caso fosse tomado como referência o abate de animais com $450 \mathrm{~kg}$ de PV. Isso resultaria em antecipação na liberação das pastagens para que fossem diferidas e recebessem nova categoria animal, mais eficiente em transformar pasto em proteína comercializável. 
Tabela 2 - Composição química dos suplementos e de pastagem de Brachiaria decumbens, em porcentagem da matéria seca

\begin{tabular}{|c|c|c|c|c|c|}
\hline \multirow[t]{2}{*}{ Item } & \multicolumn{4}{|c|}{ Suplemento } & \multirow{2}{*}{$\begin{array}{l}\text { Brachiaria } \\
\text { decumbens }^{3}\end{array}$} \\
\hline & Mistura mineral & Milho triturado & $\begin{array}{l}\text { Milho desintegrado } \\
\text { com sabugo }\end{array}$ & $\begin{array}{l}\text { Milho desintegrado } \\
\text { com palha e sabugo }\end{array}$ & \\
\hline Matéria seca (\%) & 100,00 & 88,81 & 90,87 & 91,22 & 14,83 \\
\hline Matéria orgânica ${ }^{1}$ & - & 92,08 & 92,77 & 92,60 & 91,10 \\
\hline Proteína bruta ${ }^{1}$ & - & 26,05 & 25,01 & 24,81 & 8,26 \\
\hline Compostos nitrogenados não-protéicos ${ }^{2}$ & - & 72,12 & 66,57 & 68,35 & 14,80 \\
\hline Proteína insolúvel em detergene neutro ${ }^{2}$ & - & 11,64 & 14,73 & 19,80 & 59,34 \\
\hline Proteína insolúvel em detergente ácido² & - & 0,82 & 0,94 & 1,97 & 11,18 \\
\hline Extrato etéreo ${ }^{1}$ & - & 3,22 & 3,21 & 3,22 & 2,47 \\
\hline Carboidratos totais ${ }^{1}$ & - & 62,81 & 64,55 & 64,56 & 80,37 \\
\hline Fibra em detergente neutro $(\mathrm{FDN})^{1}$ & - & 16,14 & 18,52 & 30,20 & 65,63 \\
\hline FDN isenta de cinzas e proteínas ${ }^{1}$ & - & 11,85 & 14,56 & 26,69 & 59,68 \\
\hline Carboidratos não-fibrosos ${ }^{1}$ & - & 54,72 & 53,04 & 41,17 & 14,74 \\
\hline $\mathrm{CNFc}^{1}$ & - & 59,01 & 56,99 & 44,69 & 27,50 \\
\hline Fibra em detergente ácido (FDA $)^{1}$ & - & 6,03 & 6,57 & 13,40 & 38,78 \\
\hline Lignina $^{1}$ & - & 2,93 & 3,54 & 4,22 & 9,71 \\
\hline FDN $_{\text {indigestível }}{ }^{1}$ & - & 4,39 & 5,59 & 22,57 & 17,66 \\
\hline FDA indigestível ${ }^{1}$ & - & 2,12 & 2,69 & 6,34 & 9,01 \\
\hline Nutrientes digestíveis totais estimados 4 & - & 80,11 & 78,75 & 72,82 & \\
\hline
\end{tabular}

$1 \%$ na MS; ${ }^{2} \%$ do $\mathrm{N}$ total; ${ }^{3}$ amostra obtida via extrusa esofágica; ${ }^{4}$ estimado utilizando-se as equações propostas pelo NRC (2001).

Tabela 3 - Pesos vivos iniciais e finais, ganho médio diário, rendimento de carcaça (\%) e níveis séricos de uréia obtidos com os suplementos avaliados

\begin{tabular}{lccccc}
\hline Variável & \multicolumn{2}{c}{ Suplemento } & CV (\%) & Valor-P \\
\cline { 2 - 4 } & Mistura mineral & Milho triturado & $\begin{array}{c}\text { Milho desintegrado } \\
\text { com sabugo }\end{array}$ & $\begin{array}{c}\text { Milho desintegrado } \\
\text { com palha e sabugo }\end{array}$ \\
\hline Peso vivo inicial (kg) & 384,10 & 387,10 & 384,35 & 382,85 & 11,3 \\
Peso vivo final (kg) & 461,83 & 467,04 & 477,04 & 474,18 & 0,9989 \\
Ganho médio diário (g/animal) & 922 & 996 & 1.087 & 1.084 & 14,8 \\
Rendimento de carcaça (\%) & 50,61 & 52,37 & 51,57 & 50,82 & 0,3438 \\
Uréia sérica (mg/dL) & $11,50 \mathrm{~b}$ & $23,52 \mathrm{a}$ & $19,37 \mathrm{a}$ & $20,32 \mathrm{a}$ & 0,1463 \\
\hline
\end{tabular}

${ }^{1}$ Nível descritível de probabilidade para o erro tipo I associado à hipótese de nulidade referente à ausência de efeito dos suplementos.

2 Médias na linha seguidas por letras diferentes diferem pelo teste DMS de Fisher $(P<0,10)$.

Paulino et al. (2002), em pesquisa com animais recebendo concentrado à base de milho desintegrado com palha e sabugo, observaram ganhos adicionais de $220 \mathrm{~g}$ /animal em pastagem de Brachiaria decumbens durante o período das águas. O resultado encontrado neste trabalho corrobora os obtidos por esses autores, comprovando que o milho desintegrado com palha e sabugo pode substituir o fubá de milho sem prejuízo ao desempenho produtivo dos animais, portanto é uma alternativa viável em regiões onde o milho desintegrado com palha e sabugo é encontrado com maior facilidade em comparação ao grão de milho triturado. Segundo Garcia et al. (2004), o milho desintegrado com palha e sabugo é uma fonte de alta energia e rica em fibra, o que reduz os efeitos negativos dos carboidratos prontamente fermentáveis sobre a degradação da fibra.

Na pecuária de ciclo curto, os ganhos adicionais obtidos com a suplementação no período das águas devem ser avaliados quanto ao impacto positivo causado no sistema produtivo como um todo, quanto ao possível aumento na taxa de lotação e na produção por área, e quanto à redução do tempo de terminação em confinamento ou com suplementação a pasto no período seco do ano.

Os suplementos não tiveram efeito $(\mathrm{P}>0,10)$ sobre os consumos, em kg/dia, de matéria seca e demais nutrientes (Tabela 4), com exceção do consumo de proteína bruta, que foi maior $(\mathrm{P}<0,10)$ quando os animais receberam os suplementos múltiplos. O consumo dos demais nutrientes não foi influenciado pelos níveis protéicos das dietas.

O consumo de nutrientes digestíveis totais também não foi afetado $(\mathrm{P}>0,10)$ pelos suplementos fornecidos, o que sugere que o pasto proporcionou alta quantidade de nutrientes digestíveis, pois, mesmo consumindo somente forragem, os animais ingeriram quantidades semelhantes de nutrientes digestíveis totais: em média 5,11 kg/dia ou 13,0 g/kg de PV vs 5,19 kg/dia ou 13,23 g/kg de PV com o fornecimento de suplemento. 
Tabela 4 - Consumos de nutrientes em novilhos em pastagem de Brachiaria decumbens recebendo suplementos múltiplos à base de milho

\begin{tabular}{|c|c|c|c|c|c|c|}
\hline \multirow[t]{2}{*}{ Item } & \multicolumn{4}{|c|}{ Suplemento } & \multirow[t]{2}{*}{ CV (\%) } & \multirow[t]{2}{*}{ Valor- $\mathrm{P}^{1}$} \\
\hline & Mistura mineral & Milho triturado & $\begin{array}{l}\text { Milho desintegrado } \\
\text { com sabugo }\end{array}$ & $\begin{array}{l}\text { Milho desintegrado } \\
\text { com palha e sabugo }\end{array}$ & & \\
\hline Matéria seca & 8,28 & 8,31 & 8,18 & 8,49 & 5,6 & 0,8312 \\
\hline Matéria seca do pasto & 8,22 & 7,42 & 7,27 & 7,36 & 7,9 & 0,1998 \\
\hline Matéria orgânica & 7,48 & 7,58 & 7,46 & 7,56 & 7,4 & 0,9854 \\
\hline Extrato etéreo & 0,20 & 0,21 & 0,21 & 0,21 & 7,3 & 0,8143 \\
\hline Carboidratos totais & 6,63 & 6,61 & 6,47 & 6,60 & 7,2 & 0,9615 \\
\hline Fibra em detergente neutro (FDN) & 4,29 & 4,09 & 3,91 & 4,21 & 7,8 & 0,4243 \\
\hline FDN potencialmente digestível & 2,57 & 2,44 & 2,34 & 2,49 & 7,9 & 0,4800 \\
\hline FDN indigestível & 1,72 & 1,65 & 1,56 & 1,72 & 7,8 & 0,3481 \\
\hline Carboidratos não-fibrosos & 2,28 & 2,46 & 2,33 & 2,51 & 6,9 & 0,2891 \\
\hline Matéria seca do pasto ${ }^{2}$ & $20,8 \mathrm{a}$ & $19,0 \mathrm{~b}$ & $18,7 \mathrm{~b}$ & $18,5 b$ & 5,2 & 0,0574 \\
\hline Matéria orgânica & 19,0 & 19,5 & 19,3 & 19,1 & 5,3 & 0,8994 \\
\hline Matéria orgânica do pasto $^{2}$ & $19,0 \mathrm{a}$ & $17,3 \mathrm{~b}$ & $17,1 \mathrm{~b}$ & $16,8 b$ & 5,1 & 0,0533 \\
\hline Fibra em detergente neutro (FDN) & 10,9 & 10,3 & 10,2 & 10,5 & 4,9 & 0,3308 \\
\hline FDN potencialmente digestível & 6,6 & 6,2 & 6,2 & 6,1 & 5,2 & 0,2700 \\
\hline FDN indigestível & 4,4 & 4,1 & 4,1 & 4,3 & 4,5 & 0,2249 \\
\hline NDT & 13,0 & 13,4 & 13,3 & 13,0 & 5,7 & 0,7733 \\
\hline $\mathrm{CS}^{3}$ & 0 & 0,21 & 0,23 & 0,26 & - & - \\
\hline
\end{tabular}

${ }^{1}$ Nível descritível de probabilidade para o erro tipo I associado à hipótese de nulidade referente à ausência de efeito de tratamentos.

2 Médias na linha seguidas por letras diferentes são diferentes pelo teste DMS de Fisher $(P<0,10)$.

3 Gramas de MS de suplemento por gramas de MS de forragem.

A relação entre a quantidade de matéria seca da forragem que deixou de ser consumida pela quantidade de suplemento ingerido é denominada taxa de substituição. Os coeficientes de substituição obtidos com o fornecimento de milho triturado, milho desintegrado com sabugo e milho desintegrado com palha e sabugo neste trabalho foram 0,21 ; 0,23 ; e 0,26 , respectivamente. Os coeficientes de substituição foram inferiores ao valor de 0,29 encontrado por Santos et al. (2004). Sales (2005), testando níveis crescentes de suplementação energética no período de transição águas/ seca, encontrou coeficiente de substituição de 0,42 , fornecendo um suplemento (2 kg/dia) com 30\% de proteína, à base de milho e grão de soja moído. Detmann et al. (2005a), em pesquisa com diversos níveis de proteína bruta em suplementos múltiplos no período de transição secas-águas, encontraram coeficiente de substituição superior, de $0,41 \mathrm{~g}$ de MS de forragem/g de MS de suplemento, provavelmente em virtude da quantidade de suplemento fornecida aos animais. A diferença entre os resultados está relacionada à relação proporcional entre o coeficiente de substituição e a qualidade da forragem disponível (Minson, 1990; Dixon \& Stockdale, 1999). Se a diminuição no consumo de forragem é igual à quantidade de concentrado consumida, o coeficiente de substituição é 1,0 , portanto, deseja-se que seja a menor possível. O conhecimento deste efeito tem implicações práticas e econômicas (Minson, 1990), por isso, é desejável que a utilização de suplementos otimize o uso dos recursos forrageiros pelo animal, em vez de promover sua substituição (Detmann et al., 2005a).

De acordo com Paulino et al. (2005), é importante evitar efeito associativo negativo entre a forragem e os suplementos energéticos. Quando a forragem é de qualidade média ou alta, o fornecimento de suplementos ricos em energia pode gerar um tipo de interação com os microrganismos que induz efeito negativo sobre o desaparecimento da fibra (Dixon \& Stockdale, 1999). Assim, o atendimento das necessidades totais de proteína degradada no rúmen deve ser avaliado (Paulino et al., 2005).

Quando o consumo foi considerado em relação ao peso vivo, o suplemento controle (mistura mineral) promoveu maior $(\mathrm{P}<0,10)$ consumo de matéria seca do pasto e matéria orgânica do pasto, 20,8 e 19,0 g/kg de PV, em comparação aos valores de 18,73 e 17,07 $\mathrm{g} / \mathrm{kg}$ de PV obtidos com a suplementação. 
Os consumos de matéria seca, matéria orgânica, fibra em detergente neutro e nutrientes digestíveis totais não foram influenciados $(\mathrm{P}>0,10)$ pelos suplementos.

Os limites da ingestão diária podem ser determinados primariamente por fatores de ordem metabólica (Dixon \& Stockdale, 1999). Desta forma, o fornecimento de pequena quantidade de energia prontamente fermentável no rúmen pode auxiliar no suprimento de proteína metabolizável via proteína microbiana (Poppi \& McLennan, 1995) aumentando o consumo e a produtividade em situações em que ganhos mais moderados são a meta do sistema (Detmann, 2002).
Com exceção da proteína bruta, não houve diferença significativa $(\mathrm{P}>0,10)$ na digestibilidade aparente total dos demais nutrientes. Os valores positivos para a digestibilidade aparente total da proteína bruta indicam que, para todos os suplementos, houve excesso de consumo de proteína degradável no rúmen em comparação ao perfil dos carboidratos da dieta.

Detmann et al. (2005b) observaram que a digestibilidade aparente total da proteína bruta aumentou de forma linear (70,9; 71,4; 73,4 e 76,2\%) com o aumento dos níveis de PB no suplemento (12, 16, 20 e 24\% PB, respectivamente). Valadares et al. (1997b) também encontraram aumento linear

Tabela 5 - Digestibilidades total, ruminal e intestinal de nutrientes em novilhos em pastagem de Brachiaria decumbens recebendo suplementos múltiplos à base de milho

\begin{tabular}{|c|c|c|c|c|c|c|}
\hline \multirow[t]{2}{*}{ Item } & \multicolumn{4}{|c|}{ Suplemento } & \multirow[t]{2}{*}{ CV (\%) } & \multirow[t]{2}{*}{ Valor- $\mathrm{P}^{1}$} \\
\hline & Mistura mineral & Milho triturado & $\begin{array}{l}\text { Milho desintegrado } \\
\text { com sabugo }\end{array}$ & $\begin{array}{l}\text { Milho desintegrado } \\
\text { com palha e sabugo }\end{array}$ & & \\
\hline \multicolumn{7}{|c|}{ Digestibilidade total } \\
\hline Matéria seca & 65,19 & 65,79 & 65,34 & 66,04 & 2,5 & 0,8664 \\
\hline Matéria orgânica & 67,02 & 67,52 & 67,41 & 66,47 & 2,7 & 0,8383 \\
\hline Proteína bruta ${ }^{2}$ & $61,66 b$ & $66,65 a$ & $65,81 \mathrm{a}$ & $65,15 a$ & 3,7 & 0,0964 \\
\hline Extrato etéreo & 40,10 & 41,28 & 40,29 & 40,44 & 12,1 & 0,9865 \\
\hline Carboidratos totais & 66,19 & 66,66 & 65,76 & 65,79 & 2,5 & 0,8132 \\
\hline Fibra em detergente neutro (FDN) & 68,60 & 68,73 & 68,77 & 67,73 & 4,3 & 0,9633 \\
\hline Carboidratos não-fibrosos & 71,67 & 70,41 & 72,33 & 69,64 & 3,3 & 0,4379 \\
\hline FDN potencialmente digestível & 85,33 & 83,11 & 83,95 & 83,56 & 2,3 & 0,4589 \\
\hline
\end{tabular}

${ }^{1}$ Nível descritível de probabilidade para o erro tipo I associado à hipótese de nulidade referente à ausência de efeito de tratamentos.

2 Médias na linha seguidas de letras diferentes são diferentes pelo teste DMS de Fisher $(P<0,10)$.

Tabela 6 - Digestibilidades ruminal e intestinal de nutrientes em novilhos em pastagem de Brachiaria decumbens recebendo suplementos múltiplos à base de milho

\begin{tabular}{|c|c|c|c|c|c|c|}
\hline \multirow[t]{2}{*}{ Item } & \multicolumn{4}{|c|}{ Suplemento } & \multirow[t]{2}{*}{ CV (\%) } & \multirow[t]{2}{*}{ Valor- $\mathrm{P}^{1}$} \\
\hline & Mistura mineral & Milho triturado & $\begin{array}{l}\text { Milho desintegrado } \\
\text { com sabugo }\end{array}$ & $\begin{array}{l}\text { Milho desintegrado } \\
\text { com palha e sabugo }\end{array}$ & & \\
\hline
\end{tabular}

Digestibilidade ruminal

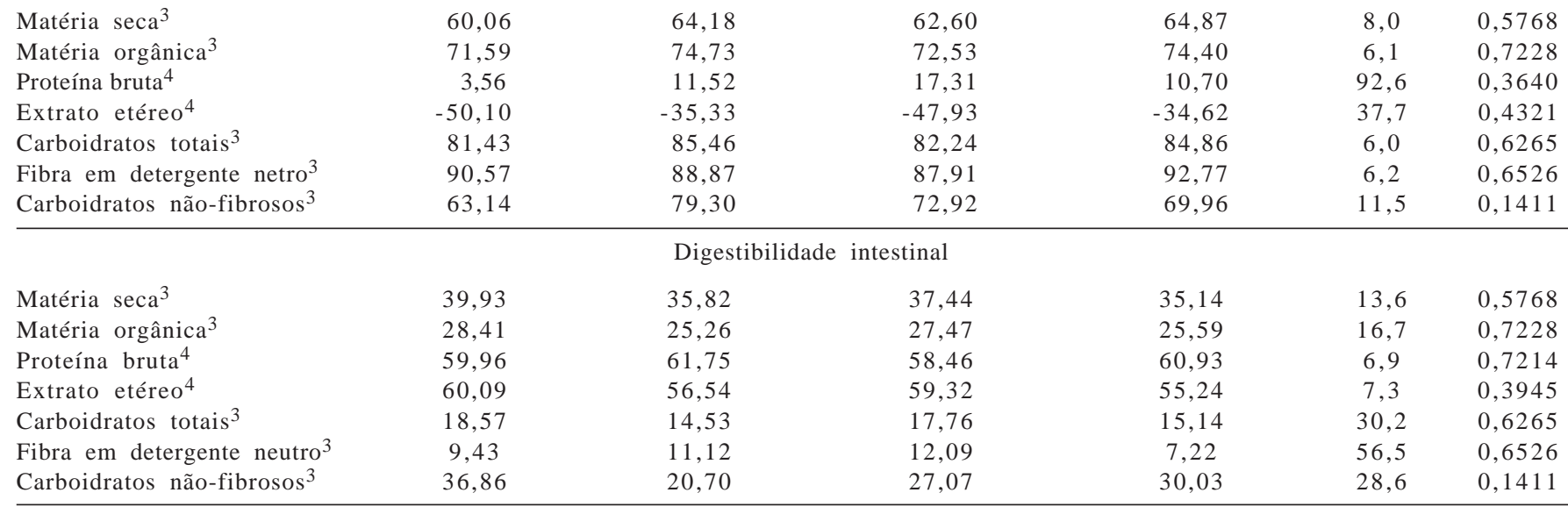

${ }^{1}$ Nível descritível de probabilidade para o erro tipo I associado à hipótese de nulidade referente à ausência de efeito de tratamentos.

2 Médias na linha seguidas por letras diferentes são diferentes pelo teste DMS de Fisher $(P<0,10)$.

$3 \%$ do total digestível.

$4 \%$ da quantidade que chegou em cada local. 
no coeficiente de digestibilidade aparente do nitrogênio com a inclusão de proteína bruta nas dietas e atribuíram essa resposta à progressiva diminuição da proporção de nitrogênio endógeno nos compostos nitrogenados fecais com o aumento da ingestão de nitrogênio. De acordo com Ørskov (1988), o nitrogênio urinário poderia diminuir e o nitrogênio fecal aumentar se maior quantidade de carboidrato fermentável chegar ao intestino grosso. Esse mesmo autor afirmou que o aumento no nitrogênio fecal ocorre de acordo com a presença de células microbianas intactas. Esse fenômeno pode não ter ocorrido neste trabalho, pois a porção de carboidratos não-fibrosos digeridos nos intestinos foi menor quando os animais consumiram suplemento (Tabela 6).

Segundo Vandehaar (1998), a redução na digestibilidade relacionada à taxa de consumo é insignificante para dietas com valores de nutrientes digestíveis totais iguais ou inferiores a $60,0 \%$. Contudo, a digestibilidade da dieta é afetada pelo consumo de forma inversamente proporcional (NRC, 2001). De acordo com Van Soest (1994), a redução na digestibilidade com o aumento no consumo depende da competição entre digestibilidade e taxa de passagem, que afeta em maior proporção as frações lentamente digestíveis da parede celular.

Os resultados obtidos neste trabalho estão de acordo com os reportados por Detmann et al. (2005b), que não verificaram mudança na digestibilidade aparente total dos carboidratos totais quando adicionaram concentrado à dieta para animais sob suplementação com diversos níveis de proteína bruta (12, 16, 20 e 24\%) no período de transição seca-águas.

O uso da suplementação no período das águas pode gerar ganhos adicionais. Contudo, o fornecimento dos suplementos múltiplos à base de milho triturado, milho desintegrado com sabugo e milho desintegrado com palha e sabugo na quantidade de $1 \mathrm{~kg} /$ dia pode reduzir o consumo de matéria seca e matéria orgânica do pasto sem alterar os consumos totais desses componentes. Quantidades menores de suplementos com essa formulação devem ser testadas em animais na fase de terminação durante o período das águas.

\section{Conclusões}

O milho desintegrado com palha e sabugo e o milho desintegrado com sabugo podem ser utilizados em substituição ao milho moído, principalmente para melhorar a relação custo/beneficio da dieta, no entanto, o milho, sob qualquer forma testada, quando utilizado na quantidade de $1 \mathrm{~kg} /$ dia, reduz o consumo de matéria seca e matéria orgânica do pasto.

\section{Literatura Citada}

CAPPELLE, E.C.; VALADARES FILHO, S.C.; SILVA, J.F.C. Estimativas do consumo e do ganho de peso de bovinos, em condições brasileiras Revista Brasileira de Zootecnia, v.30, n.6, p.1857-1865, 2001.

COCHRAN, R.C.; ADAMS, D.C.; WALLACE, J.D. et al. Predicting digestibility of different diets with internal markers: Evaluation of four potential markers. Journal of Animal Science, v.63, n.5, p.1476-1483, 1986.

DETMANN, E.; PAULINO, M.F.; ZERVOUDAKIS, J.T. et al. Cromo e indicadores internos na estimação do consumo de novilhos mestiços, suplementados, a pasto. Revista Brasileira de Zootecnia, v.30, n.5, p.1600-1609, 2001a.

DETMANN, E.; PAULINO, M.F.; ZERVOUDAKIS, J.T. et al. Níveis de proteína bruta em suplementos múltiplos para terminação de novilhos mestiços em pastejo durante a época seca: desempenho produtivo e características de carcaça. Revista Brasileira de Zootecnia, v.33, n.1, p.169-180, 2004.

DETMANN, E.; PAULINO, M.F.; CECON, P.R. et al. Níveis de proteína em suplementos para terminação de bovinos em pastejo durante o período de transição seca/águas: consumo voluntário e trânsito de partículas. Revista Brasileira de Zootecnia, v.34, n.4, p.1371-1379, 2005 a.

DETMANN, E.; PAULINO, M.F.; CECON, P.R. et al. Níveis de proteína em suplementos para terminação de bovinos em pastejo durante o período de transição seca/águas: digestibilidade aparente e parâmetros do metabolismo ruminal e dos compostos nitrogenados. Revista Brasileira de Zootecnia, v.34, n.4, p.1380-1391, 2005b.

DIXON, R.M.; STOCKDALE, C.R. Associative effects between forages and grains: consequences for feed utilization. Australian Journal Agricultural Research, v.50, n.5, p.757-773, 1999.

EUCLIDES, V.P.B.; MACEDO, M.C.M.; OLIVEIRA, M.P. Avaliação de diferentes métodos para se estimar o valor nutritivo de forragens sob pastejo. Revista Brasileira de Zootecnia, v.21, n.4, p.691-702, 1992.

GARCIA, J.; ALCALDE, C. R.; ZAMBOM, M. A. et al. Desempenho de novilhos em crescimento em pastagem de Brachiaria decumbens suplementados com diferentes fontes energéticas no período da seca e transição seca-águas. Revista Brasileira de Zootecnia, v.33, n.6, p.2140-2150, 2004 (supl. 2).

HALL, M.B. Calculation of non-structural carbohydrates content of feeds that contain non-protein nitrogen. Gainesville: University of Florida, 2000. p.A-25 (Bulletin 339).

LEÃO, M.I.; COELHO DA SILVA, J.F.; CARNEIRO, L.H.D.M. Implantação de fístula ruminal e cânula duodenal reentrante em carneiros, para estudos de digestão. Ceres, v.25, n.1, p.42-54. 1978.

LICITRA, G.; HERNANDEZ, T.M.; Van SOEST, P.J. Standardization of procedures for nitrogen fractionation of ruminant feeds. Animal Feed Science and Technology, v.57, p.347-358, 1996.

McMENIMAN, N.P. Methods of estimating intake of grazing animals. In: REUNIÃO ANUAL DA SOCIEDADE BRASILEIRA DE ZOOTECnIA, 34., 1997, Juiz de Fora. Anais... Juiz de Fora: Sociedade Brasileira de Zootecnia, 1997. p.131-168.

MINSON, D.J. Forage in ruminant nutrition. Academic Press: New York, 1990. 483p.

NATIONAL RESEARCH COUNCIL - NRC. Nutrient requirements of dairy cattle. 7.ed. Washington, D.C.: National Academy Press, 2001. 381p

NATIONAL RESEARCH COUNCIL - NRC. Nutrient requirements of beef cattle. 7.ed. Washington, D.C.: National Academic Press, 1996. 234p.

ØRSKOV, E.R. Nutrición proteica de los ruminantes. Zaragoza: Acribia, 1988. 178p. 
PAULINO M.F.; MORAES E.H.B.K.; ZERVOUDAKIS, J.T. et al. Suplementação de novilhos mestiços recriados em pastagens de Brachiaria decumbens durante o período das águas: desempenho. In: REUNIÃO ANUAL DA SOCIEDADE BRASILEIRA DE ZOOTECNIA, 39., 2002, Recife. Anais... Recife: Sociedade Brasileira de Zootecnia, 2002. (CD-ROM).

PAULINO, M.F.; MORAES, E.H.B.K.; ZERVOUDAKIS, J.T. et al. Fontes de energia em suplementos múltiplos de auto-regulação de consumo na recria de novilhos mestiços em pastagens de brachiaria decumbens durante o período das águas. Revista Brasilerira de Zootecnia, v.34, n.3, p.957-962, 2005.

PAULINO, M.F.; DETMANN, E.; VALADARES FILHO, S.C. Suplementação animal em pasto: energética ou protéica?. In: SIMPÓSIO SOBRE MANEJO ESTRATÉGICO DA PASTAGEM, 3., 2006, Viçosa, MG. Anais... Viçosa, MG: SIMFOR, 2006. p.359-392.

POPPI, D.P.; McLENNAN, S.R. Protein and energy utilization by ruminants at pasture. Journal of Animal Science, v.73, p.278290, 1995.

SALES, M.F.L.; PAULINO, M.F.; PORTO, M.O. et al. Níveis de energia em suplementos múltiplos para terminação de novilhos em pastagem de capim-braquiária no período de transição águasseca. Revista Brasileira de Zootecnia, v.37, n.4, p.724733, 2008.

SANTOS, E.D.G.; PAULINO, M.F.; VALADARES FILHO, S.C. et al. Terminação de tourinhos Limousin $\mathrm{x}$ Nelore em pastagem diferida de Brachiaria decumbens Stapf, durante a estação seca, alimentados com diferentes concentrados. Revista Brasileira de Zootecnia, v.33, n.6, p.1627-1637, 2004.

SATTER, L.D.; SLYTER, L.L. Effect of ammonia concentration on rumen microbial protein production in vitro. British of Journal Nutrition, v.32, p. 199-208, 1974.

SILVA, D.J.; QUEIROZ, A.C. Análise de alimentos: métodos químicos e biológicos. 3.ed. Viçosa, MG: Universidade Federal de Viçosa, 2002.165p.

VALADARES FILHO, S.C.; ROCHA JR., V.R.; CAPELLE, E.R. Tabelas brasileiras de composição de alimentos para bovinos. Viçosa, MG: Universidade Federal de Viçosa, 2002. 297p.

VALADARES, R.F.D.; GONÇALVES, L.C.; SAMPAIO, I.B. et al. Níveis de proteína bruta em dietas de bovinos. 2. Consumo, digestibilidades e balanço de compostos nitrogenados. Revista Brasileira de Zootecnia, v.26, n.6, p.1259-1263, 1997a.

VALADARES, R.F.D.; GONÇALVES, L.C.; RODRIGUEZ. N.M. et al. Níveis de proteína bruta em dietas de bovinos. 4. Concentração de amônia ruminal, uréia plasmática e excreções de creatinina. Revista Brasileira de Zootecnia, v.26, n.6, p.1270-1278, 1997b.

Van DEHAAR, M. Efficiency of nutrient use and relationship to profitability on dairy farms. Journal of Dairy Science, v.81, p.272-282, 1998.

Van SOEST, P.J. Nutritional ecology of the ruminant. 2.ed. Ithaca: Cornell University, 1994. 476p 